\title{
„Książki, szwarc, mydło i powidło...” Dystrybucja książek na wsi w latach pięćdziesiątych XX w. w świetle dokumentów Centralnego Urzędu Wydawnictw, Przemysłu Graficznego i Księgarstwa
}

Jednym z priorytetów planu sześcioletniego (1950-1955) było upowszechnianie czytelnictwa ze szczególnym uwzględnieniem rozwoju czytelnictwa na wsi. Lata 1952-1953 to okres nasilonych prób kolektywizacji rolnictwa i przymuszania chłopów do przystępowania do spółdzielni produkcyjnych. Oprócz metod represyjnych sposobem na przekonanie chłopów do zmian miała być tzw. rewolucja kulturalna. Władza przykładała wielką wagę do propagandowej roli odpowiednio dobranej literatury mającej wpłynąć na mentalność chłopów i spowodować pożądane przemiany społeczno-gospodarcze ${ }^{1}$.

Pierwsze próby rozpowszechniania książek w małych miastach i na wsi podjęły w latach 1947 i 1948 spółdzielcze organizacje księgarskie. Około 600 punktów sprzedaży ${ }^{2}$ posiadały spółdzielnie nadzorowane przez Związek Rewizyjny Spółdzielni Rzeczypospolitej Polskiej³. W 1948 r. uruchomiono w Warszawie wysyłkową księgarnię rolniczą. Centralna Księgarnia Rolnicza „Samopomoc Chłopska” miała realizować indywidualne zamówienia, jak i wysyłać komplety książek wraz z szafkami przeznaczone do rozprzedaży w sklepach wiejskich. CRK sa-

${ }^{1}$ Zob. m.in.: A. Dobieszewski, Kolektywizacja wsi polskiej 1948-1956, Warszawa 1993; A. Kura, Aparat bezpieczeństwa i wymiar sprawiedliwości wobec kolektywizacji wsi polskiej 1948-1956, Warszawa 2006; D. Jarosz, Polityka wtadz komunistycznych w Polsce w latach 1948 -1956 a chtopi, Warszawa 1998; D. Jarosz, Obraz chtopa w krajowej publicystyce czasopiśmienniczej 1944-1959, Warszawa 1994.

${ }^{2}$ A. Klimowicz, Księgarstwo, Warszawa 1953, s. 23.

${ }^{3}$ W.A. Ciszewska, Źródta do badań nad dziejami ksiązki lat 1945-1950, [w:] Biuletyn EBIB, 2007, nr 1 http://www.ebib.info/2007/82/ciszewska.php [15 I 2013]. 
ma wydawała książki o tematyce rolniczej, które rozprowadzała poprzez gminne spółdzielnie. Akcją dystrybucyjną objęto ponad tysiąc takich placówek $^{4}$. CRK propagowała swoją ofertę poprzez ogłoszenia prasowe. W 1950 r. dystrybucję książek przejęła od niej nowo powstała Centrala Obrotu Księgarskiego „Dom Książki”.

W aktach Centralnego Urzędu Wydawnictw, Przemysłu Graficznego i Księgarstwa ${ }^{6}$ (CUWPGiK) znajdujących się w Archiwum Akt Nowych, zachowały się różnego rodzaju dokumenty mówiące o problemach zaopatrzenia wsi w książki w latach stalinizmu. System dystrybucji oparty był na sklepach GS prowadzonych przez Centralę Rolniczą Spółdzielni „Samopomoc Chłopska” (CRS „SCh”) zorganizowanych na podstawie zarządzenia o upowszechnianiu i kolportażu książek wydanego przez Prezydium Rady Ministrów w styczniu 1950 roku . Oprócz tego książki rozprowadzali kolporterzy społeczni i listonosze (czasopisma i literaturę masową, m.in. Ludowej Spółdzielni Wydawniczej, będącą w ofercie Państwowego Przedsiębiorstwa Kolportażu „Ruch”). Sklepy GS zaopatrywane były przez Centralę Obrotu Księgarskiego „Domu Książki” podległej CUWPGiK za pośrednictwem struktur CRS „SCh”. Plan finansowy dla „Domu Książki” na 1950 r. przewidywał, że do wiejskich sklepów trafi 7,8\% masy towarowej, która miał on rozprowadzić. Plan został wykonany zaledwie w $40 \%{ }^{8}$. W $1951 \mathrm{r}$. zakładano sprzedaż w GS-

${ }^{4}$ J. Friemann, Stan i potrzeby dystrybucji oraz czytelnictwa książki rolniczej, Przegl. Bibliot., 22:1954, z. 2, s. 125.

${ }^{5}$ Zarządzenie Prezesa Rady Ministrów z dnia 15 stycznia 1950 r. o utworzeniu przedsiębiorstwa państwowego pod nazwą Centrala Obrotu Księgarskiego „Dom Książki”. M.P., 1950, nr 7, poz. 72; L. Biliński, Książka w Polsce Ludowej. Wydawnictwa i ksiegarstwo, Warszawa 1981, s. 121-122; P. Kitrasiewicz, Ł. Gołębiewski, Rynek książki w Polsce 1944-1989, Warszawa 2005, s. 33-37.

${ }^{6}$ Urząd ten powstał w sierpniu 1951 r. z połączenia Centralnej Komisji Wydawniczej i centralnych zarządów: Przemysłu Graficznego i Księgarstwa Do listopada 1956 r. podporządkowane mu były wszystkie instytucje wydawnicze $\mathrm{z}$ wyjątkiem tzw. resortowych, ale faktycznie poprzez wyłączną dyspozycję papierem na druk książek, nadzór nad wszystkimi niemal drukarniami dziełowym, monopol sprzedaży, uprawnienia w dziedzinie honorariów, dysponowanie etatami i funduszem bezosobowym oraz dewizami posiadał on decydujący wpływ na całość ruchu wydawniczego w Polsce. Do zadań CUWPGiK należała m.in. kontrola realizacji wytycznych kierownictwa politycznego w planach wydawniczych, nadzór nad treściami ideowymi oraz stroną wychowawczo-artystyczną i edytorską książki, ustalanie perspektyw rozwoju przemysłu graficznego, wydawnictw i księgarstwa oraz upowszechnianie czytelnictwa. Zob.: Dekret $z$ dnia 2 sierpnia 1951 r. o utworzeniu i zakresie działania CUWPGiK, DzU, 1951, nr 41, poz. 309; AAN, Centralny Urząd Wydawnictw, Przemysłu Graficznego i Księgarstwa (dalej: CUWPGiK), 1, k. nlb., Regulamin Kolegium Centralnego Urzędu Wydawnictw, Przemysłu Graficznego i Księgarstwa.

7 AAN, CUWPGiK, 379, k. 75, T. Szteinert, Analiza czytelnictwa na terenie województwa olsztyńskiego, referat z dn. 31 V 1953.

${ }^{8}$ S.A. Kondek, Papierowa rewolucja, Warszawa 1999, s. 60. 
ach na poziomie aż 22158 tys. egzemplarzy ${ }^{9}$. I te plany nie zostały zrealizowane. Wśród powodów takiego stanu rzeczy należy wymienić nieprzygotowanie GS-ów do sprzedaży książek oraz źle dobraną ofertę w $1950 \mathrm{r}$. były to przede wszystkim tytuły zalegające magazyny. W $1951 \mathrm{r}$. sytuację ratowała sprzedaż podręczników.

W 1950 roku na wsi funkcjonowało 26825 sklepów, a w 1955 r. ich liczba doszła do $41936^{10}$. Nie wszystkie jednak miały w ofercie książki. Według zleconych przez Biuro Rady Czytelnictwa i Książki sprawozdań z terenu w 1953 r. w każdej gminie np. województwa krakowskiego działały sklepy GS (186) oraz ok. 300 punktów sprzedaży detalicznej w gromadach $^{11}$. W 1954 r. wszystkie te sklepy powinny prowadzić sprzedaż książek. Jednak krakowska ekspozytura „Domu Książki” podawała, że była w stałych kontaktach z ok. 150 sklepami GS i był to nawet spadek w stosunku do 1953 r.

\section{Ze szmatami i naftą}

Pod koniec lat czterdziestych sieć handlową w powiatach próbował rozwijać Związek Rewizyjny Spółdzielni. Powstało ok. 600 punktów prowadzonych przez spółdzielnie księgarskie. Jednak były to raczej sklepy papiernicze, które tylko ok. jednej czwartej obrotów dokonywały książką.

Początkowo akcja rozpowszechniania książek przez sklepy wiejskie zakończyła się niepowodzeniem. GS-y nie potrafiły sprzedawać książek. Sklepy te znajdowały się często w chałupach wiejskich, ciemnych i ciasnych, gdzie nie było miejsca na ekspozycję książek, które były „ze szmatami, z naftą, gdzieś w kącie, bez żadnej propagandy wzrokowej"12. Jak wykazały kontrole prowadzone m.in. przez CUWPGiK w 1953 r., w wielu sklepach książki ustawiono obok butelek z wódką, na bocznych półkach zasłoniętych innymi towarami np. płaszczami lub skrzynkami z jabłkami, chowano pod kontuarem lub składowano wprost na podłodze; znajdowano też książki z grzbietami pogryzionymi przez myszy ${ }^{13}$.

\footnotetext{
${ }^{9}$ Tamże, s. 63.

${ }^{10}$ Rocznik statystyczny 1959, Warszawa 1959, s. 241.

11 AAN, CUWPGiK, sygn. 379 k. 38, Zagadnienie dystrybucji i sprzedaży książek na wsi na podstawie sprawozdań z terenu [1953-1954].

12 AAN, CUWPGiK, 377, k. nlb., Stenogram z pierwszego plenarnego posiedzenia Rady Czytelnictwa i Książki z 15 czerwca 1953.

13 AAN, CUWPGiK, 375, k. nlb., Lustracja [placówek sieci księgarskiej]. Sprawozdania [1952] - 1953 .
} 
Aby wspomóc dystrybucję w ekspozyturach wojewódzkich „Domu Książki” zatrudniono 300 instruktorów powiatowych, których zadaniem było instruowanie gminnych spółdzielni w sprawie sprzedaży książek, a w 1952 r. postanowiono, że mają powstać specjalne komórki zajmujące się sprzedażą książki na wsi w PZGS, WZGS i CRS „SCh”14. Oficjalnie sytuacja poprawiła się w drugiej połowie 1951 roku po zainteresowaniu się problemem dystrybucji książek na wsi przez rady narodowe oraz zaangażowaniu w połowie $1952 \mathrm{r}$. nauczycieli i młodzieży ${ }^{15}$. W rzeczywistości GS-y, aby zrealizować plan sprzedaży wymuszały kupno książek razem $\mathrm{z}$ towarami deficytowymi lub wydawały je zamiast reszty (przede wszystkim tanie broszury typu Biblioteki Gromady), a nawet kupowały książki dla swoich związkowych bibliotek ${ }^{16}$. Inną formą rozpowszechniania książek na wsi było np. wykorzystywanie ich w formie biletów wstępu na potańcówkę, czy jako wygranej na loterii. Natomiast listonosze rozprowadzający na wsi ofertę „Ruchu”17 przy doręczaniu listu poleconego żądali kupna książki ${ }^{18}$ lub prowadzili handel wymienny - pobierali trzy jaja za jedną książkę ${ }^{19}$.

Sprzedaż książek stanowiła nikłą część ogólnej sprzedaży prowadzonej przez GS-y; np. w województwie krakowskim w 1953 r. przeciętna sprzedaż miesięczna wódki przynosiła 50-70 tys. zł, a książek często kształtowała się na poziomie groszowym ${ }^{20}$. Sklepy w powiecie pułtuskim prowadziły nawet sprzedaż wiązaną - wódki i książek, szczególnie tych mało chodliwych, bo kupujący alkohol patrzyli tylko na ostatnia stronę okładki z ceną, a nie na tytuł ${ }^{21}$.

${ }^{14}$ AAN, CUWPGiK, 3, knlb., Notatka z konferencji wspólnej Przedstawicieli Naczelnej Dyrekcji „Domu Książki” i Zarządu Głównego CRS „Samopomoc Chłopska” odbytej w dniu 24 grudnia $1952 \mathrm{r}$.

${ }^{15}$ AAN, CUWPGiK, 379, k. 75, T. Szteinert, Analiza czytelnictwa ...

${ }^{16}$ AAN, CUWPGiK, 377, k. nlb., Stenogram z pierwszego plenarnego...

17 „Ruch” przejął od GS-ów kolportaż książek w 1956 r. Planowano wtedy otwarcie tysiąca kiosków. Za: K. Remerowa, Czytelnictwo wiejskie, [w:] Ogólnopolski Zjazd Bibliotekarzy - Warszawa 16-18 lutego 1956 - Ksiegga pamiątkowa, Warszawa 1957, s. 188.

18 AAN, CUWPGiK, 2, k. nlb., Protokół Nr 4 z posiedzenia Prezydium Centralnego Urzędu Wydawnictw z 20 lutego 1952 r.

19 AAN, CUWPGiK, 375, k. nlb., Sprawozdanie z przeprowadzonej w dniach 4-9 kwietnia br. [1953] przez St. Radcę Smolika Kazimierza lustracji badań rozdzielnictwa nowości i wtórnych zamówień na terenie działalności olsztyńskiej ekspozytury oraz wizytacji 6 GS-ów na terenie powiatów Pasłęk, Ostróda, Mrągowo i Giżycko.

${ }^{20}$ AAN, CUWPGiK, 65, k. nlb., K. Borajkiewicz, Sprawozdanie z badań dotyczących obrotu wydawnictwami na szczeblu WZGS - Kraków i gminnych spółdzielni (delegacja służbowa 20.03-27.03.1953).

${ }^{21}$ Sprawozdanie syntetyczne z pobytu ekip delegowanych do 8 powiatów województwa kieleckiego, poznańskiego, warszawskiego i wrocławskiego dla zbadania stanu czytelnictwa na wsi (12-16 lutego 1953 r.), Zbiory Instytutu Książki i Czytelnictwa Biblioteki Narodowej. 
Średnia wojewódzka zakupu książek na 1 mieszkańca wsi województwa krakowskiego za 10 miesięcy 1953 r. wynosiła 2,14 zł; jeżeli za przeciętną cenę książki łącznie z podręcznikami szkolnymi przyjmiemy 3 zł, to średnio jeden mieszkaniec wsi krakowskiej kupił 0,70 egzemplarza ${ }^{22}$. Udział wsi w ogólnych zakupach książek był niski. Wskaźniki te niewiele zmieniły się w latach sześćdziesiątych. Potwierdziły to badania Radosława Cybulskiego ${ }^{23}$ na podstawie analizy sprzedaży Małej encyklopedii powszechnej $P W N$ - w 1961 r. mieszkaniec Warszawy wydał na książki 134,87 zł na książki, województwa warszawskiego 15,10 zł, a powiatu Iłża 2,14 zł (były to średnie wydatki na książki w miejscowej księgarni na mieszkańca powiatu, w tym także wydatki bibliotek).

\section{Wykonanie planu sprzedaży na zero}

Podczas kontroli przeprowadzonej w marcu 1953 r. na zlecenie CUWPGiK w WZGS Kraków i podległych gminnych spółdzielniach przeprowadzono wizytacje łącznie w dziesięciu sklepach GS, Sklepach Artykułów Potrzeb Kulturalnych, punkcie sprzedaży detalicznej i PZGS-ie ${ }^{24}$.

W Sklepie Artykułów Potrzeb Kulturalnych w Niepołomicach (sprzedającym książki, papier, kosmetyki, artykuły sportowe), sprzedawca nie znał planu sprzedaży książek. Działał jeden kolporter, ale brakowało dokumentacji z rozliczeń z wziętych w komis wydawnictw. Sprzedawca nie prowadził także kontrolki sprzedaży. Zestaw tytułowy książek, według kontrolującego placówkę, był szeroki i obejmował duży wybór literatury dziecięcej, społeczno-politycznej, rolniczej i beletrystyki. Lokal przeznaczony na sklep był ciasny, więc książki znajdowały się „wszędzie, gdzie tylko się spojrzy na półkach, pod ladą, na ziemi, na regałach między obuwiem i piłkami" "25. Sprzedawca mimo braku wsparcia ze strony PZGS starał się promować sprzedaż książek. W drugim z wizytowanych Sklepów Artykułów Potrzeb Kulturalnych w Poroninie sytuacja była znacznie lepsza. Sprzedawczyni prowadziła kontrolkę sprzedaży. Książki ułożone były na półkach działami i alfabetycznie na co wpływ miał, że sklepem kierowała od niedawna osoba $\mathrm{z}$ wykształceniem licealnym, która przez trzy lata prowadziła bibliotekę gimnazjalną. Również w tym

${ }^{22}$ AAN, CUWPGiK, 379, k. 38, Zagadnienie dystrybucji i sprzedaży książek na wsi...

${ }^{23}$ Cyt. za St. Siekierski, Recepcja literatury pięknej na wsi, Warszawa 1967, s. 52.

${ }^{24}$ AAN, CUWPGiK, sygn. 65, knlb., K. Borajkiewicz, Sprawozdanie z badań dotyczących obrotu ...

25 Tamże. 
sklepie kontroler stwierdził szeroki zakres tytułowy i tematyczny, dużo książek dziecięcych i rolniczych. Te ostatnie nie cieszyły się jednak zainteresowaniem klientów.

Kontrola sześciu sklepów GS wykazała małą sprzedaż książek lub jej brak, jak w przypadku GS-u w Trzebini, gdzie w połowie lutego 1953 r. książki przeniesiono do osobnego pomieszczenia przeznaczonego na Sklep Artykułów Potrzeb Kulturalnych, który jednak nie został otwarty. Oficjalnie trwał remanent, ale zabicie wejścia deskami nie wróżyło szybkiego jego otwarcia. Sprzedaży książek nie prowadził także GS w Pcimiu w powiecie myślenickim. Ustalony na 300 zl plan sprzedaży w styczniu i lutym 1953 r. nie został w ogóle wykonany, tzn. w styczniu jego realizacja wynosiła „zero”, w lutym nie wiadomo, bo zabrakło danych, na marzec w ogóle nie było planu. GS nie prowadził kontrolki sprzedaży książek, kolportażu ani sprzedaży stoiskowej w dni targowe. Natomiast kontroler stwierdził bardzo duży wybór beletrystyki, literatury społecznopolitycznej i rolniczej oraz wydawnictw dziecięcych, wśród których były tzw. wydania „lipskie” z 1952 r. Sprzedawca przyznal, że zamówienia na książki opracowuje PZGS bez udziału i zasięgania w niego informacji co do potrzeb czytelniczych klientów. W GS-ie w Wojniczu książki ułożone były bezładnie na niemal niedostępnych półkach. Podobnie sytuacja wyglądała w sklepie w Zabierzowie, gdzie książki chaotycznie wciśnięto na trzy półki. W tym GS-ie duża ilość książek dziecięcych stanowiła atrakcję loteryjną. W obu nie prowadzono kolportażu.

Tylko jeden sprzedawca z poddanych kontroli sklepów przeszedł tygodniowe szkolenie księgarskie w Krakowie - z GS w Mogilanach. Osiągnął on przybliżoną sprzedaż książek w styczniu 1953 r. w wysokości 150 zł, natomiast wódki - 30 tys. zł. Obrót alkoholem w ośmiu filialnych sklepach wynosiła 50 tys. zł, a książek - 500 zł. Na jednego z 2500 mieszkańców gminy przypadało zatem miesięcznie, jak wyliczył kontroler - wódki za 2 zł i książek za 20 gr. Podobne proporcje obowiązywały w GS w Kościelisku, gdzie miesięczny handel wódką wynosiła 20 tys. zł, a książek 120 zł. Za tyle sprzedano ich w styczniu 1953 r. młodzieży z koloni. W Kościelisku działał także nowo otwarty punkt sprzedaży detalicznej, którego właścicielka 21 marca 1953 r. po raz pierwszy otrzymała paczkę z książkami na sumę 600 zł o tematyce dziecięcej i rolniczej. Podczas wizytacji przyznała, że dużym zbytem cieszą się wydawnictwa młodzieżowe (J. Verne, Dzieci kapitana Granta) i tanie broszurki dla dzieci.

W Sklepie Potrzeb Artykułów Kulturalnych w Lipnicy Murowanej sprzedaż książek wzrastała w czerwcu, kiedy szkoła kupowała nagrody 
dla uczniów i przed Mikołajem ${ }^{26}$. Część rozprowadzana była poprzez loterie. Sklep miał na stanie we wrześniu 1953 r. książek za ok. 5300 zł i plan sprzedaży na wrzesień w wysokości 1500 zł. Kierownik zamawiał głównie lektury, bajki, poradniki np. o przetworach owocowych, ale jego zamówienia nie były brane pod uwagę i dostawał książki z rozdzielnika. Planów samodzielnie nie wykonywał, więc jego kierownik posyłał książki do biura sprzedaży węgla, cementu czy nawozu, gdzie chłopów zmuszano do ich kupna. Częste były zatem przypadki rzucania książek w błoto tuż po wyjściu z biura. W 1953 r. plan sprzedaży książek przez krakowski WZGS wykonano w 82,1\%27.

W marcu 1953 r. do ekspozytury „Domu Książki” w Krakowie wpłynęło łącznie z dwunastu GS-ów zamówień na książki na sumę 6 tys. zł. Nie zostały one jednak zrealizowane w pełni ze względu na braki w magazynach. Powszechnym zjawiskiem było zwracanie przez sklepy paczek z książkami.

Największe obroty wykazywały Sklepy Artykułów Potrzeb Kulturalnych w miejscowościach kuracyjnych - do 2 tys. zł miesięcznie ${ }^{28}$. Dane z ekspozytury „Domu Książki” wskazywały, że większość mieszkańców wsi zaopatrywała się w księgarniach powiatowych, szczególnie w podręczniki szkolne.

\section{W pakiecie z Leninem i Stalinem}

Zaopatrzenie sklepów GS w nowości następowało poprzez rozdzielnik centralny, którego wielkość co do liczby egzemplarzy i tytułów ustalała każdorazowo na dane województwo CRS „SCh”. W rzeczywistości rozdzielniki sporządzano mechanicznie według ustalonego procentu, bez brania pod uwagę zainteresowań ludności. Sklepy podzielone były z reguły na kilka kategorii: sklepy GS tzw. sklepy artykułów potrzeb kulturalnych, sklepy GS znajdujące się w pobliżu zakładów przemysłowych oraz spółdzielni przemysłowych; sklepy GS w mniejszych miejscowościach oraz te, które miały najmniejszy obrót księgarski ${ }^{29}$. Do pierwszych dwóch grup sklepów trafiało $60 \%$ towaru, pozostałe otrzymywały dalsze $40 \%$. Rozdzielnik centralny CRS realizowany był w całości, ale pokrywał tylko od 30 do $40 \%$ wartości planu zakupu. Resztę planu wy-

${ }^{26}$ AAN, CUWPGiK, 380, k. 49, M. Bielawska, Śladem książki w Lipnicy Murowanej.

27 AAN, CUWPGiK, 380, k. 14, Tabela wykonania planu sprzedaży WZGS woj. krakowskiego w $1953 \mathrm{r}$.

${ }^{28}$ AAN, CUWPGiK, 379, k. 38, Zagadnienie dystrybucji i sprzedaży książek na wsi...

${ }^{29}$ Tamże, k. 39. 
konywano poprzez: tzw. rozdzielnik wojewódzki, który sporządzał kierownik sekcji księgarskiej Wojewódzkiego Zarządu Gminnych Spółdzielni (WZGS) z wyboru w magazynach „Domu Książki”, rozdzielniki sporządzane przez instruktorów księgarskich Powiatowych Zarządów Gminnych Spółdzielni (PZGS) oraz poprzez zamówienia wtórne GS-ów (były niewielkie i nie miały wpływu na wykonanie planu zakupu).

System centralnego zakupu, nie liczący się z potrzebami czytelników, wykorzystywany zresztą często przez „Dom Książki” do upłynniania mało „chodliwych” tytułów powodowal, że w wiejskich GS-ach można było dostać książki poszukiwane w mieście; sklep GS w Radzyminie oferował spory wybór tytułów radzieckich, które w Warszawie zostały rozprzedane. W powiecie nie cieszyły się powodzeniem, zdaniem lustrującego go inspektora, ze względu na brak znajomości języka rosyjskiego ${ }^{30}$. Często terenowe ekspozytury „Domu Książki” wysyłały do GS-ów książki drogie i zbyt trudne np. Gleboznawstwo Wasilija Williamsa, O sytuacji w biologii Trofima Lysenki, Dziennikarstwo Tadeusza Z. Hanusza, które zalegały półki.

Do 1954 r. wydano 1950 tytułów literatury rolniczej w nakładzie $25 \mathrm{mln}$ egzemplarzy. Oprócz tego różne resorty rozprowadziły bezpłatnie na wsi $25 \mathrm{mln}$ egzemplarzy broszur i ulotek ${ }^{31}$, zresztą często pokrywających się tematycznie $\mathrm{z}$ tymi będącymi w sprzedaży oraz w bibliotekach. Skierowane były głównie do pracowników spółdzielni produkcyjnych i państwowych gospodarstw rolnych. Dla indywidualnych chłopów przygotowywano broszury kampanijne $\mathrm{z}$ doraźnymi zaleceniami powtarzanymi z roku na rok ${ }^{32}$. „Dom Książki” w 1953 r. przeprowadził badania 90 GS-ów w dziewięciu województwach (łódzkie, stalinogrodzkie, zielonogórskie, poznańskie, wrocławskie, rzeszowskie, krakowskie i kieleckie), które wykazały, że chłopi nie chcieli czytać literatury rolniczej o zbożu, hodowli świń, których to pozycji „Dom Książki” miał najwięcej, a poszukiwali pozycji o pszczelarstwie, sadownictwie, gospodarstwie domowym czy gotowaniu, których brakowało ${ }^{33}$. Analogiczna sytuacja dotyczyła zawartości księgozbiorów bibliotecznych, gdzie literatura rolnicza stanowiąca $9 \%$ księgozbioru w $60-70 \%$ pochodziła z lat $1947-50$ i były

${ }^{30}$ AAN, CUWPGiK, 65, k. nlb., Sprawozdanie z wyjazdu do Radzymina powiat Wołomin w celu zebrania stanu czytelnictwa [1952].

31 Tamże, k. nlb., Pismo do Centralnego Urzędu Wydawnictw z 2 listopada 1954 r. z Wydziału Propagandy i Agitacji KC PZPR.

32 A. Bromberg, Ksiażki $i$ wydawcy. Ruch wydawniczy $w$ Polsce Ludowej $w$ latach 1944-1957, Warszawa 1958, s. 188.

${ }^{33}$ AAN, CUWPGiK, 377, k. nlb., Stenogram z pierwszego plenarnego... 
to głównie wieloegzemplarzowe broszurki. W latach 1948-1949 masowo wydawano przekłady radzieckie, a w 1952 r. - drobne broszury z poradami sezonowymi związanymi z nieurodzajem. Jednak większość z nich zalegała magazyny „Domu Książki”. W latach 1951-1953 Państwowe Wydawnictwo Rolnicze i Leśne wydało także znaczną ilość przekładów radzieckich książek rolniczych, bez adaptacji do warunków polskich. Przeprowadzono także akcję wydawniczą propagującą teorie Miczurina i Łysenki. Nakłady rolniczych broszur rosły od 1951 r. (1,7 mln) do 1954 r. $(8,7 \mathrm{mln})^{34}$, kiedy to podczas II Zjazdu PZPR w związku z niedostatecznym wzrostem produkcji rolnej postanowiono przyspieszyć rozwój rolnictwa.

Wykorzystanie literatury rolniczej w bibliotekach obliczano średnio na 3 proc., zatem większość pozycji było martwych ${ }^{35}$.

Mała sprzedaż powodowała gromadzenie się nadmiernych remanentów (zapasów), szczególnie w latach 1950-1952 r. Dotyczyło to głównie książek nie odpowiadających poziomowi czytelnika wiejskiego, wydawnictw zdezaktualizowanych, tytułów uznanych za „szkodliwe” i wycofanych. Poza tym CRS Komunikatem Handlowym nr 6 wprowadził w 1953 r. zakaz dokonywania zwrotów zarówno nowości, jak i zrealizowanych zamówień, co było częstą praktyką (np. w województwie zielonogórskim GS-y nie przyjmowały paczek, zwłaszcza z literaturą rolniczą, wysyłanych przez „Dom Książki” na podstawie zamówieńn ${ }^{36}$ ). Prezesi i księgowi GS-ów bronili się w ten sposób przed wzrostem remanentów, starając się utrzymać rentowność i rotację towaru ${ }^{37}$.

Szkolenie sprzedawców wiejskich odnośnie sprzedaży książek nie przynosiło oczekiwanego efektu, bowiem bardzo często się oni zmieniali, nawet co miesiąc. Arkusze zamówień bywały używane w GS-ach jako papier do pakowania, podobnie jak ulotki, czy katalogi wydawnicze, które trafiały pod ladę lub „pakowano w nie śledzie”38. Jednak w niektórych sklepach inspektorzy CUW spotykali się z propagandą książek. W sklepie artykułów potrzeb kulturalnych w Niepołomicach wysiłek sprzedawcy włożony w sprzedaż książek reprezentował umieszczony na jednej ze ścian odręcznie sporządzony plakat „Kup dziecku

${ }^{34}$ A. Bromberg, dz. cyt., s. 182.

${ }^{35}$ K. Remerowa, dz. cyt., s. 191-193.

${ }^{36}$ AAN, CUWPGiK, 379, k. 39, Zagadnienie dystrybucji i sprzedaży książek na wsi...

37 AAN, CUWPGiK, 375, k. nlb., Sprawozdanie z przeprowadzonych badań, mających na celu ustalenie sposobu rozdzielnictwa nowości i realizacji zamówień wtórnych dla GS Samopomoc Chłopska [27 VII -1 VIII 1953, WZGS i ekspozytura wojewódzka „Domu Książki” w Lodzi].

${ }^{38}$ AAN, CUWPGiK, 377, k. nlb., Stenogram z pierwszego plenarnego... 
bajkę"39. Tania literatura dziecięca cieszyła się jako jedyna autentycznym powodzeniem w wiejskich sklepach.

\section{„Wszystko przez wielkopańskość wydawców”}

W 1951 r. „Dom Książki” sprzedał GS-om książek (oprócz podręczników) za 12,2 mln zł, czyli zrealizowano plan tylko w 32 proc. W 1952 r. nastąpiło załamanie planu sprzedaży hurtowej i detalicznej na skutek źle dobranej tematyki i błędów organizacyjnych kolportażu. Według planu osiągnięto wtedy wprawdzie 46,4 proc. planu, ale kwotowo było to tylko o 700 tys. zł więcej w stosunku do 1951 roku $^{40}$. Plan na 1953 r. był ponad dwukrotnie wyższy od zrealizowanego w poprzednim roku, ale zarówno Zarząd Główny Centrali Rolniczych Spółdzielni (ZG CRS), jak i Naczelna Dyrekcja „Domu Książki” uznały na wspólnej naradzie pod koniec 1952 r., że jest możliwa jego realizacja, jeśli „stworzone zostaną odpowiednie warunki".

W związku z tym postanowiono w 1953 r. uruchomić 300 sklepów artykułów potrzeb kulturalnych, co miało dać w sumie na koniec roku 500 takich placówek. Oprócz tego sieć kolporterów miała objąć pracowników GS, członków ZMP, Ligi Kobiet czy młodzież szkolną. Uzgadnianie wzajemne tematyki książek przeznaczonych dla wsi, powołanie, a właściwie przejęcie przez CRS z „Domu Książki” specjalnych komórek instruktażowych, nowy system płac mający zainteresować pracowników CRS dystrybucją książki ${ }^{41}$. Członek zarządu, planista czy tez zaopatrzeniowiec będący także „organizatorem sprzedaży książek” otrzymywał $5 \%$ od ogólnej sumy otrzymanej ze sprzedaży książek na terenie całej gminy $^{42}$. Książki miano także sprzedawać na targach i jarmarkach poprzez loterie fantowe. W praktyce referaty księgarskie miały niewystarczającą obsadę personalną. Sklepy nie były powiadamiane o planach sprzedaży wydawnictw, nie prowadzono kontrolek sprzedaży książek, wizytacje sklepowe o charakterze księgarskim przeprowadzano rzadko i chaotycznie. Nie doprowadzono także od współpracy GS-ów z nauczycielstwem i organizacjami masowymi. Przy niektórych działali kolporterzy na zasadzie komisu.

${ }^{39}$ AAN, CUWPGiK, 65, k. nlb., K. Borajkiewicz, Sprawozdanie z badań ...

${ }^{40}$ Tamże, k. nlb., J. Marecki, Dystrybucja książki na wsi. [Referat, 1953].

${ }^{41}$ AAN, CUWPGiK, 3, k. nlb., Notatka z konferencji wspólnej Przedstawicieli Naczelnej Dyrekcji „Domu Książki” i Zarządu Głównego CRS „Samopomoc Chłopska” odbytej w dniu 24 grudnia 1952 r.

42 J. Friemann, dz. cyt., s. 132. 
Reorganizacja ta przeprowadzona na początku 1953 r. nie wzmocniła organizacyjnie i nie usystematyzowała metod pracy z książką. Zmieniająca się wielokrotnie kadra instruktorów przekazana przez „Dom Książki” WZGS-om okazała się niezdolna do polepszenia metod pracy na wsi.

Gminne Spółdzielnie oskarżały „Dom Książki”, że jeszcze w okresie samodzielnej dystrybucji zarzucił GS-y „trudnymi” tytułami. Ten ripostował, że ściśle przestrzega zamówień i uskarżał się z kolei na częste zwroty i żądał wstrzymania zamówień wskutek wysokich remanentów. WZGS w Krakowie jako przyczynę niskiego wykonywania planu sprzedaży książek wskazywał przesyłanie książek do sklepów na swoim terenie z innych ekspozytur „Domu Książki” - np. Wrocławia, Warszawy co miało także dezorganizować pracę ${ }^{43}$.

Sprawozdania dla CUWPGiK wykazały także na zbyt powolny rozwój sieci księgarskiej w 1953 r. Planu rozbudowy Sklepów Artykułów Potrzeb Kulturalnych, których podstawowym artykułem były książki, nie wykonano. Nie rozszerzono również sprzedaży książek na większą ilość sklepów gromadzkich. Wiele zastrzeżeń budził także kolportaż, który był niewspółmiernie mały w stosunku do możliwości. Oprócz kolportażu szkolnego i kiermaszy nie prowadzono innych form upowszechniania książki.

Narastający problem dystrybucji książki na wsi postanowiono rozwiązać pod koniec 1954 r. Wydział Propagandy i Agitacji KC PZPR uznał, że zasadnicza poprawa i podwojenie 1955 r. sprzedaży książki na wsi ma nastąpić poprzez:

- rozbudowę przez CRS w miejscowościach poniżej powiatu, szczególnie w siedzibach większych, gromad, sieci sklepów papierniczoksięgarskich, tak aby było ich tysiąc do końca 1955;

- rozbudowę sieci księgarskiej przez CZK tak, aby w siedzibie każdego powiatu była co najmniej jedna księgarnia;

- podniesienie poziomu propagandy poprzez specjalne audycje o książkach w radiowęzłach, czy łączenie występów amatorskich zespołów artystycznych z propagandą książki;

- uruchomienie w każdej gromadzie wypożyczalni (w 1955 r. miało powstać 2000 nowych bibliotek) ${ }^{44}$.

43 AAN, CUWPGiK, 65, k. nlb., Pismo Wojewódzkiego Związku Gminnych Spółdzielni „Samopomoc Chłopska” w Krakowie z 12 marca 1953 r. do Zarządu Handlu, Wydział Księgarski Centrali Rolniczej Spółdzielni „Samopomoc Chłopska” w Warszawie.

44 Tamże, k. nlb., Pismo do Centralnego Urzędu Wydawnictw z 2 listopada 1954 r. 
Działania te spowodowały, że w 1955 r. w miastach powiatowych działały często aż trzy księgarnie (punkty sprzedaży książek) - „Domu Książki”, „Ruchu” i GS-u ${ }^{45}$.

Wydział Propagandy i Agitacji KC PZPR przyczyn niepowodzeń w upowszechnianiu czytelnictwa na wsi upatrywał m.in. w braku odpowiedniej literatury ideologiczno-propagandowej, skierowanej do chłopów. W 1954 r. Wydział zauważył, że „Książka i Wiedza” dopiero w akcji wyborczej do rad narodowych wydała kilka broszur popularnie wyjaśniających chłopu istotę władzy ludowej, politykę partii i rządu. Poza tym wprawdzie „Książka i Wiedza” oraz Ludowa Spółdzielnia Wydawnicza usiłowały popularyzować przodujące doświadczenia chłopów indywidualnych, spółdzielców, robotników PGR i zespołów uprawowych, ale większość $\mathrm{z}$ wydawanych broszur nie dość konkretnie pokazywała istotę nowatorskich metod i nie uczyła, jak je stosować w konkretnych warunkach glebowych. Podobnie było z pokaźną literaturą o spółdzielniach produkcyjnych, która miała charakter sztampowy, a siła jej oddziaływania była niewielka.

\begin{abstract}
Powtarza się stare, wytarte argumenty omijając sprawy drażliwe, nie odpowiada śmiało na pytania i wątpliwości chłopów, na kułackie kłamstwa. Sprawy samorządu wewnętrznego spółdzielni, dyscypliny i organizacji pracy, los starców i podobne zagadnienia tak pasjonujące chłopów i zniekształcane przez kułaka - nie zostały należycie wyjaśnione, w oparciu o praktykę naszych spółdzielni. Nieprzezwyciężona do końca jest szkodliwa maniera lakierowania rzeczywistości (jaskrowo wystąpiło to w niepotrzebnie wydanych przez LSW złych reportażach pt. W spótdzielni produkcyjnej żyje się lepiej i Na żotnierskim szlaku). Zamazując trudności, nie oświetlając żmudnej walki, po której spółdzielnie doszły do swych osiągnięć, umniejsza się wielkość tych osiągnięć i co główne, nie uczy się innych, jak je zdobywać ${ }^{46}$.
\end{abstract}

Winą za niepowodzenia spółdzielni produkcyjnych obarczano także literaturę, w której brak było analizy przyczyn ich słabości i wskazań, jak im pomóc. Zdaniem centralnych władz partyjnych nie dość dobrze pokazywana była złożoność walki klasowej, nie odsłaniano „całej perfidii kułaka, jego nowych metod penetracji i argumentacji”. Poważny zarzut dotyczył braku literatury o pracy partyjnej na wsi. Wydział zauważył, że „Książka i Wiedza” nie wydała dotychczas literatury syntetycznie wyjaśniającej chłopu sytuację międzynarodową, kwestię Niemiec, walkę

${ }^{45}$ AAN, CUWPGiK, 8, k. nlb., Protokół nr 10 Kolegium CUWPGIK z dnia 1 czerwca 1955. Sprawozdanie z działalności Centralnego Zarządu Księgarstwa za 1954 r.

${ }^{46}$ AAN, CUWPGiK, 65, k. nlb., Pismo do Centralnego Urzędu Wydawnictw z 2 listopada $1954 \mathrm{r}$. 
chłopów w koloniach. Wysiłek partii w utrwalaniu świadomości o nieuchronności rozwoju spółdzielczości produkcyjnej niweczony był przez wydawnictwa, które nie apelowały do patriotyzmu chłopa, nie mówiły nic o sytuacji międzynarodowej i o przewadze sił pokoju na świecie. Popularyzacja wiedzy rolniczej oderwana od propagandy zespołowej gospodarki, powodowała, że na wsi brak było pasji w walce z zacofaniem gospodarczym. Jako typowy przykład „złego” wydawnictwa Wydział Propagandy i Agitacji KC PZPR wskazał broszurę Felicjana Dębińskiego Kiedy i jak siać, w której nie wspomniano o brygadzie spółdzielczej oraz możliwościach i korzyściach zespalania się chłopów indywidualnych dla wspólnej uprawy. W zaleceniach, których realizacja miała spowodować zwielokrotnienie oddziaływania literatury na przekształcenia społeczno-gospodarcze wsi, skierowanych przez partię do CUW, znalazło się m.in. polecenie „wytrzebienia resztek wielkopańskiego stosunku wydawców do sprawy wsi”, a także wprowadzenie obowiązku dyskutowania planów wydawniczych i książek (przed drukiem) z aktywem wiejskim, popularyzacja ZSRR i jego wszechstronnej pomocy dla Polski oraz propaganda kołchozów, czyli tego, „jak ludzie radzieccy łamiąc trudności osiągają lepsze życie" 47 .

Dokumenty CUWPGiK pokazują, że działania w zakresie kolportażu książki na wsi były pozorne i motywowane logiką systemu gospodarki centralnie planowanej, a nie rzeczywistymi potrzebami odbiorców wiejskich.

\section{Streszczenie}

\section{„Książki, szwarc, mydło i powidło...”}

Dystrybucja książek na wsi w latach pięćdziesiątych XX w. w świetle dokumentów Centralnego Urzędu Wydawnictw, Przemysłu Graficznego i Księgarstwa

Książki kolportowane były na wsi w latach pięćdziesiątych XX w. głównie poprzez sieć sklepów Gminnych Spółdzielni „Samopomoc Chłopska” oraz kolporterów społecznych i listonoszy rozprowadzających ofertę „Ruchu”. Natomiast GS-y zaopatrywane były przez „Dom Książki” za pośrednictwem struktur Centrali Rolniczych Spółdzielni „Samopomoc Chłopska”. „Dom Książki” od 1951 r. podlegał powstałemu wtedy Centralnemu Urzędowi Wydawnictw Przemysłu Graficznego i Księgarstwa (CUWPGiK). Urząd ten przejął scentralizowane zarządzanie proce-

\footnotetext{
47 Tamże.
} 
sami produkcji i dystrybucji książek i przez pięć lat posiadał decydujący wpływ na całość ruchu wydawniczego w Polsce. W aktach CUWPGiK znajdujących się w Archiwum Akt Nowych, zachowały się różnego rodzaju dokumenty mówiące o problemach zaopatrzenia wsi w książki. Początkowo akcja rozpowszechniania książek przez sklepy wiejskie zakończyła się niepowodzeniem, bowiem nie były one przygotowane zarówno lokalowo jak i organizacyjnie do rozprowadzania takiego towaru. Sprzedawcy często nawet nie rozpakowywali przesyłek z „Domu Książki” lub wręcz je odsyłali. W 1951 r. zrealizowano plan sprzedaży na wsi tylko w 32\%, w 1952 r. w 46\%. Aby zrealizować plan sprzedaży GS-y wymuszały kupno książek razem z towarami deficytowymi lub wydawały je zamiast reszty. Zaopatrzenie sklepów w nowości następowało poprzez rozdzielnik centralny, którego wielkość co do liczby egzemplarzy i tytułów ustalała każdorazowo na dane województwo CRS „SCh”. W rzeczywistości rozdzielniki sporządzano mechanicznie według ustalonego procentu, bez brania pod uwagę zainteresowań ludności. Szkolenie sprzedawców wiejskich odnośnie sprzedaży książek nie przynosiło oczekiwanego efektu, bowiem bardzo często się oni zmieniali. Na początku 1953 r. próbowano zreorganizować dystrybucję książki na wsi, ale podjęte działania ani nie wzmocniły jej organizacyjnie, ani nie usystematyzowały metod pracy z książką. Narastający problem dystrybucji książki na wsi postanowiono rozwiązać ponownie pod koniec 1954 r. Tym razem działania te spowodowały, że w 1955 r. w miastach powiatowych działały często aż trzy księgarnie (punkty sprzedaży książek) - „Domu Książki”, „Ruchu” i GS-u. Wydział Propagandy i Agitacji KC PZPR przyczyn niepowodzeń w upowszechnianiu czytelnictwa na wsi upatrywał m.in. w braku odpowiedniej literatury ideologiczno-propagandowej, skierowanej do chłopów.

\section{Summary}

\section{"Books, shoeshine, soap and jam..." Provision of Books for the Rural Areas of Poland in the Nineteen-Fifties \\ in the Light of the Archival Materials of the Central Bureau of Publications, Typographical Industry and Bookselling}

During the nineteen-fifties, in the Polish countryside, books were circulated chiefly by the network of the „Peasant Cooperative” shops, by volunteers, and by postmen, who offered to the customers the books of the company „Ruch”. The books available in the „Peasant Cooperative” shops were provided by the company „Dom Książki”, obtained through the intermediary structures of the Central Offices of the Farmers Cooperatives. Starting with 1951 through the next five years, production and distribution of books in Poland was supervised by the Central Bureau of Publications, Typographical Industry and Bookselling. The archives of this institution, nowadays kept at the Central Archives of Modern Records in Warsaw, demonstrate that selling books to the peasants encountered various problems. Initially, the idea 
of selling books in village shops proved a disappointment. These shops had neither the necessary room nor the trained personnel to vend printed matter. The shopkeepers often wouldn't even bother to unpack the books, but sent them back immediately. In 1951, the overall bookselling plan was realized only at the level of $32 \%$, rising a year later to $46 \%$. To reach that level the village shopkeepers combined selling books with deficit wares, or gave books instead of the change. The number and destination of newly published books always went in accord with a central plan, which was worked out in administrative capitals of provinces. These plans were based on a mechanical division of the numbers of books appointed to locations, regardless of actual needs. Training the shopkeepers in vending books also proved ineffective, because of the high level of personnel rotation in shops. At the beginning of 1953, there was an attempt at establishing a system of distribution, but the undertaken activities brought little authentic change. The second attempt, launched towards the end of 1954, brought more effect. In result, in 1955, even small towns could often boast three bookshops (or so called selling „points”), run by the „Dom Książki” company, the „Ruch” company, and the „Peasant Cooperative” vendors. At the same time, within the Propaganda and Campaigning Division of the Central Committee of the Communist party in Warsaw there prevailed the conviction that failure of the readership programme among the peasantry was mainly due to lack of adequate ideological and propaganda literature. 
